\title{
Performance and Egg Quality of Laying Hens Fed with Boiled Tomato Waste Powder
}

\author{
Maria Endo Mahata ${ }^{1 *}$, Taufik Hidayat ${ }^{1}$, Gina Amalia Nurhuda ${ }^{1}$, Yose Rizal $^{1}$ and Ardi $^{2}$ \\ ${ }^{1}$ Nutrition and Feed Technology Departement, Faculty of Animal Science,Universitas Andalas, 25163, Indonesia \\ ${ }^{2}$ Agronomy Department, Faculty of Agriculture, Universitas Andalas, 25163, Indonesia \\ *Correspondent author's E-mail: maria@ ansci.unand.ac.id; ORCID: 0000-0002-4692-9806
}

Received: 07 Dec. 2020

Accepted: 19 Jan. 2020

\begin{abstract}
This study was performed to evaluate the effect of inclusion of boiled tomato waste powder in laying hens diet on growth performances and egg quality. Tomato waste used in this experiment was surplus and unsold mature tomato from the last harvest on the field. The tomato waste was boiled in boiling water $\left(100^{\circ} \mathrm{C}\right)$ for 8 minutes to convert their lycopene structure from trans to $c i s$, which is easily absorbed by the poultry digestive tract. In a completely randomized design, 200 Isa Brown laying hens were divided into five groups with different inclusion levels of boiled tomato waste powder $(0,3,6,9$ and $12 \%)$ in an iso-nitrogenous $(16 \%)$ and iso-caloric $(2600 \mathrm{kcal} / \mathrm{kg})$ diet. Daily feed intake, hen day egg production, egg weight, egg mass, feed conversion ratio, eggshell thickness, and eggshell strength were measured. The obtained results showed that boiled tomato waste powder in the diet did not significantly affect daily feed intake, feed conversion ratio, egg production and egg quality. In conclusion, the tomato boiled powder could be used up to $12 \%$ in laying hens diet with no effect on performance and egg quality of laying hens.
\end{abstract}

Key words: Diet, Egg quality, Layer performance, Lycopene, Tomato

\section{INTRODUCTION}

Tomato production in Indonesia continues to increase, in 2016 as much as 883,234 tons and in 2017 reached 962,849 tons (Badan Pusat Statistik Indonesia, 2017). Raw tomato contains lycopene as much as $9.25 \mathrm{mg} / 100 \mathrm{~g}$ (Perveen et al., 2015). The lycopene compounds can act as antioxidants (Muller et al., 2011) and also reduce cholesterol in blood serum, egg yolk, and broiler meat (Mahata et al., 2016a; and Mahata et al., 2016b). The lycopene inhibits cholesterol synthesis through inhibition of HMG-CoA reductase activity, modulation of lowdensity lipoprotein receptor activity and inhibition of acylCoA:cholesterol acyltransferase (Palozza et al., 2012). In fresh tomato, lycopene is in trans form, which is difficult to absorb in the digestive tract of poultry, while cislycopene can be more easily absorbed (Knockaert et al., 2012; Cooperstone et al., 2015). The heating process of tomatoes by steaming, boiling and roasting increases the availability of lycopene in cis form (Sahlin et al., 2016; and Handayani et al., 2018). The boiled tomato waste can be used up to $7 \%$ in broiler rations to lower cholesterol in meat and blood serum with no effect on the performance (Mahata et al., 2016a). There are little report on the use of boiled tomato waste in rations of laying hens, therefore, this research was conducted to evaluate the effects of boiled tomato waste on performance and egg quality of laying hens.

\section{MATERIALS AND METHODS}

\section{Ethical approval}

The present study was approved by the Animal Ethics Committee of the Universitas Andalas, Padang, Indonesia (No: 456/KEP/FK/2019).

\section{Poultry}

The experiment was performed by using 200 laying hens strain of ISA Brown at the age of 32 weeks with $80 \%$ hen day egg production condition.

\section{Boiled tomato waste powder preparation}

Fresh tomato waste was boiled in boiled water at 100 ${ }^{\circ} \mathrm{C}$ for 8 minutes. Then, it was sun-dried and powdered by a grinder. 


\section{Experimental design}

The experiment was conducted in a completely randomized design with five treatment group, including different inclusion levels $(0,3,6,9$ and $12 \%)$ of boiled tomato waste powder in laying hens diets. Each treatment was replicated four times. Each replicate consisted of five birds. Diets were formulated iso-protein (16\%) and isoenergy $(2990 \mathrm{kcal} / \mathrm{kg}$ diet $)$ and composition of diets are presented in table 1 . The experiment lasted for 60 days.

Table 1. Diet composition and chemical analysis of experimental diets

\begin{tabular}{lcccc}
\hline \multirow{2}{*}{ Ingredients (\%) } & \multicolumn{3}{c}{ Experimental diets supplemented with different levels of boiled tomato waste } \\
powder
\end{tabular}

\section{Measured variables}

\section{Daily feed intake} equation:

Daily feed intake was calculated by the following

Daily feed intake $=$

The amount of diet given for 1 week-The amount of diet left over 1 week 7 day

\section{Hen day egg production}

Hen day egg production was measured by method described by Cesari et al. (2014) according to following equation:

$$
\text { Hen day egg production }=\frac{\begin{array}{c}
\text { The number of eggs produced on the } \\
\text { day of measurement }
\end{array}}{\begin{array}{c}
\text { The number of laying hens that live on the } \\
\text { day measurement }
\end{array}} 100 \%
$$

\section{Egg weight}

Egg weight was estimated by the following formula: Egg weight $=\frac{\text { Egg weight produced by laying hens in each unit }}{\text { The number of eggs produced each unit }}$

\section{Egg mass}

The egg mass was calculated by the method described by Cesari et al. (2014) according to following formula:

Egg mass $=$ Hen day egg production (\%) $\times$ Egg weight $(g)$

\section{Feed conversion ratio}

Feed conversion ratio was calculated by the method described by Kulshreshtha et al. (2014).
Feed conversion ratio $=\frac{\text { Ration consumed }(\mathrm{kg})}{\text { Egg production } \times \text { Egg weight }(\mathrm{kg})}$

\section{Haugh unit}

Haugh unit is an indicator of albumen quality. Eggs were weighed using a digital scale and then broken. The egg shards were placed on a flat glass, then the height of the albumen was measured using a caliper. Haugh unit was calculated according to (Haugh, 1937).

\section{Eggshell thickness}

The eggshell thickness was measured by using the method described by Aydin et al. (2008). The eggshell thickness was measured in three parts, namely the equator, the air bag, and the tip of the egg section. Measurement results from the three sections were averaged to get the eggshell thickness. The instrument used was a screw micrometer.

\section{Eggshell strength}

Eggshell strength was measured using the Egg Force Reader (SHIMPO FGV-10XY).

\section{Statistical analysis}

Data were analyzed by analysis of variance (ANOVA) using a general linear model procedure using SPSS software version 16.0. The difference among treatment means was determined by using Duncan's multiple range test $(\mathrm{p}<0.05)$. 


\section{RESULTS AND DISCUSSION}

The inclusion of boiled tomato waste powder in laying hens diet did not significantly affect feed conversion ratio, egg mass, egg weight, hen day egg production, and daily feed intake (Table 2). The boiled tomato waste powder also did not significantly affect Haugh unit, eggshell thickness, and eggshell strength of laying hens (Table 3). The inclusion of boiled tomato waste powder in laying hens diet up to $12 \%$ did not affect the daily feed intake due to similar palatability of treatment diets. Similarly, An et al. (2019) demonstrated that inclusion of synthetic lycopene or tomato paste in laying hens diet did not affect daily feed intake. Furthermore, Lee et al. (2016) reported that the inclusion of lycopene on broiler's ration did not affect feed consumption. The average daily feed intake of laying hens in this study ranged from 116.47 to 121.30 $\mathrm{g} / \mathrm{bird}$. This finding was approximately similar to results obtained by Panaite et al. (2019) who found daily feed intake of laying hens fed a diet supplemented with flaxseed and dried tomato ranged from 120 to $217 \mathrm{~g} / \mathrm{bird}$. All inclusion levels of boiled tomato waste powder used in this experiment did not affect hen day egg production, egg weight, and egg mass. Some previous studies reported the inclusion of $190 \mathrm{~g} / \mathrm{kg}$ dried tomato pomace, $6 \%$ tomato waste meal, $25 \mathrm{~g} / \mathrm{mg}$ lycopene, and $16 \%$ dried tomato pomace had no effects on hen day egg production, egg weight, egg mass, and feed conversion ratio (Salajegheh et al., 2012; Habanabashaka et al., 2014; Jalalinasab et al., 2014).
The inclusion of boiled tomato waste powder in laying hens diet did not affect Haugh unit, eggshell thickness, and eggshell strength of laying hens (Table 3). It has been reported that the inclusion of lycopene in laying hens diet did not have an effect on the Haugh unit (Honda et al., 2019; An et al., 2019). The average Haugh unit of laying hens in this study ranged from 69 to 81 . Honda et al. (2019) reported that the Haugh unit of eggs from laying hens fed with lycopene-supplemented diet ranged from 5.80 to 91.90 . In this experiment, the inclusion of boiled tomato waste powder up to $12 \%$ in diet also did not affect the eggshell thickness and eggshell strength. This finding can be attributed to the similar content of calcium and phosphorus in each treatment diet. According to Ahmed et al. (2013), calcium is one of the nutrients that influence the eggshell quality and production of laying hens. Eggshell strength of laying hens fed 2.62\% calcium in the diet was more weakness than that of laying hens fed diet containing 3.70 to $4.4 \%$ calcium (Jiang et al., 2013). Some studies reported that the addition of tomato powder, flaxseed and dried tomato flour to laying hens diet did not affect the thickness and strength of eggshell (Akdemir et al., 2012; and Panaite et al., 2019). The average of eggshell thickness in this study ranged from 0.409 to $0.430 \mathrm{~mm}$, and the eggshell strength ranged from 3.43 to $4.62 \mathrm{~kg} / \mathrm{cm}^{2}$. These results were similar to that reported by An et al. (2019) who found eggshell thickness and eggshell strength of eggs from laying hens fed with lycopene or tomato paste were $0.35-0.36 \mathrm{~mm}$ and 4.39 $4.74 \mathrm{~kg} / \mathrm{cm}^{2}$, respectively.

Table 2. Average of daily feed intake, hen day egg production, egg weight, and egg mass of laying hens fed with different inclusion levels of boiled tomato waste powder

\begin{tabular}{lccccc}
\hline $\begin{array}{l}\text { Inclusion levels of boiled tomato } \\
\text { waste powder in diet }\end{array}$ & $\begin{array}{c}\text { Daily feed intake } \\
\text { (g/bird/day) }\end{array}$ & $\begin{array}{c}\text { Hen day egg } \\
\text { production }(\boldsymbol{\%})\end{array}$ & $\begin{array}{c}\text { Egg weight } \\
\text { (g) }\end{array}$ & $\begin{array}{c}\text { Egg mass } \\
\text { (g) }\end{array}$ & $\begin{array}{c}\text { Feed conversion } \\
\text { ratio }\end{array}$ \\
\hline $0 \%$ & 116.47 & 83.34 & 61.98 & 51.62 & 2.29 \\
$3 \%$ & 121.59 & 89.83 & 62.18 & 55.89 & 2.18 \\
$6 \%$ & 119.41 & 88.33 & 62.09 & 54.89 & 2.19 \\
$9 \%$ & 118.37 & 86.92 & 62.9 & 54.77 & 2.18 \\
$12 \%$ & 121.30 & 89.17 & 62.65 & 55.89 \\
\hline
\end{tabular}

Table 3. Average of Haugh unit, eggshell thickness, and eggshell strength of laying hens fed with different inclusion levels of boiled tomato waste powder

\begin{tabular}{lccc}
\hline $\begin{array}{l}\text { Inclusion levels of boiled tomato waste powder in } \\
\text { diet }\end{array}$ & Haugh unit & $\begin{array}{c}\text { Eggshell thickness } \\
(\mathbf{m m})\end{array}$ & $\begin{array}{c}\text { Eggshell strength } \\
\left(\mathbf{k g} / \mathbf{c m}^{2}\right)\end{array}$ \\
\hline $0 \%$ & 81.21 & 0.425 & 3.89 \\
$3 \%$ & 77.47 & 0.409 & 4.29 \\
$6 \%$ & 69.22 & 0.429 & 4.62 \\
$9 \%$ & 79.44 & 0.430 & 4.63 \\
$12 \%$ & 70.19 & 0.421 & 3.43 \\
\hline
\end{tabular}




\section{DECLARATIONS}

\section{Acknowledgments}

This research was a second year competency grant scheme funded by the Directorate General of Higher Education Republic of Indonesia in 2017. We are grateful to the Minister of Education Republic of Indonesia and LPPM Universitas Andalas.

\section{Author's contribution}

Maria Endo Mahata created the idea, designed the study and drafted the manuscript. Taufik Hidayat and Gina Amalia Nurhuda collected data and performed statistical analysis. Yose Rizal and Ardi created the idea and designed the study.

\section{Competing interests} interests.

The authors declared that they have no competing

\section{REFERENCES}

Abudabos AM, Al-Owaimer AN, Hussein EOS and Ali MH (2019). Effect of natural vitamin $\mathrm{C}$ on performance and certain haematobiochemical values in broiler chickens exposed to heat stress. Pakistan Journal of Zoology, 50(3): 951-955. DOI: http://dx.doi.org/10.17582/journal.pjz/2018.50.3.951.955.

Ahmed NM, Atti KAA, Elamin KM, Dafalla KY, Malik HEE and Dousa BM (2013). Effect of dietary calcium sources on laying hens performance and egg quality. Journal of Animal Production Advances, 3(7): 226-231. DOI: https://doi.org/10.3390/ani9030110

Akdemir FC, Orhan N, Sahin, Sahin DK and Hayirli A (2012). Tomato powder in laying hen diets: effects on concentrations of yolk carotenoids and lipid peroxidation. British Poultry Science, 53(5): 675-680. DOI:https://doi.org/10.1080/00071668.2012.729142.

An BK, Choo WD, Kang CW, Lee J and Lee KW (2019). Effects of dietary lycopene or tomato paste on laying performance and serum lipids in laying hens and on malondialdehyde content in egg yolk upon storage. Japan Poultry Science Association, 56: 52-57. DOI: https://doi.org/10.2141/jpsa.0170118.

Aydin R, Karaman M, Cicek T and Yardibi H (2008). Black cumin (Nigella sativa L.) supplementation into the diet of the laying hen positively influences egg yield parameters, shell quality, and decrease egg cholesterol. Poultry Science, 87: 2590-2595. DOI: https://doi.org/10.3382/ps.2008-00097.

Badan Pusat Statistik Indonesia (2017). Statistik tanaman buah-buahan dan sayuran semusim Indonesia 2017. No. Publikasi: 05120.1808. Katalog: 5205009. Available at: https://www.bps.go.id/publication/2018/10/05/bbd90b867a6ee372e 7f51c43/statistik-tanaman-sayuran-dan-buah-buahan-semusimindonesia-2017.html

Cesari V, Mangiagalli MG, Giardini A, Galimberti P, Carteri S, Gallazzi D and Toschi I (2014). Egg quality and productive performance of laying hens fed different levels of skimmed milk powder added to a diet containing Lactobacillus acidophilus. Poultry Science, 93(5): 1197-1201. DOI: https://doi.org/10.3382/ps.2013-03518.

Cooperstone JL, Ralston RA, Riedl KM, Haufe TC, Schweiggert RM, King SA, Timmers CD, Francis DM, Lesinski GB, Clinton SK and Schwartz SEJ (2015). Enhanced bioavailability of lycopene when consumed as cis-isomers from tangerine compared to red tomato juice, a randomized, cross-over clinical trial. Molecular Nutrition and Food Research, 59(4): 658-669. DOI: https://doi.org/10.1002/mnfr.201400658

Habanabashaka M, Sengabo M and Oladunjoye IO (2014). Effect of tomato waste meal on lay performance, egg quality, lipid profile and carotene content of eggs in laying hens. Iranian Journal of Applied Animal Science, 4(3): 555-559. DOI: https://doi.org/10.1.1.845.4280.

Handayani UF, Wizna, Suliansyah I, Rizal Y and Mahata ME (2018) Effects of heating method on lycopene, dry matter and nutrient content of tomato (lycopersicon esculentum) waste as laying hen feed. International Journal of Poultry Science, 17(2): 63-70. DOI: https://doi.org/10.3923/ijps.2017.63.70

Haugh RR (1937). The Haugh unit for measuring egg quality. United States Egg and Poultry Magazine, 43: 522-555.

Honda M, Ishikawa H and Hayashi Y (2019). Alterations in lycopene concentration and $Z$-isomer content in egg yolk of hens fed all- $E$ isomer-rich and Z-isomer-rich lycopene. Animal Science Journal, 90(9): 1261-1269. DOI: https://doi.org/10.1111/asj.13276

Ilahy R, Siddiqui MW, Tlili I, Montefusco A, Piro G, Hdider C and Lenucci MS (2018). When color really matters: horticultural performance and functional quality of high-lycopene tomatoes. Critical Reviews in Plant Sciences, 37(1): 1-39. DOI: https://doi.org/10.1080/07352689.2018.1465631.

Jalalinasab A, Nobakht A and Razzaghzadeh S (2014). The effect of different levels of tomato pomace and processing methods on production performance and blood metabolites of native laying hens. Iranian Journal of Applied Animal Science, (2): 379-385. Available at: http://ijas.iaurasht.ac.ir/article_513701.html.

Jiang S, Cui L, Shi C, Ke X, Luo J and Hou J (2013). Effects of dietary energy and calcium levels on performance, engshell quality and bone metabolism in hens. The Veterinaty Journal, 198: 252-258. DOI: https://doi.org/10.1016/j.tvj1.2013.07.017.

Knockaert G, Pulissery SK, Colle I, Van Buggenhout S, Hendrickx M and Loey AV (2012). Lycopene degradation, isomerization and in vitro bioaccessibility in high pressure homogenized tomato puree containing oil: Effect of additional thermal and high pressure processing. Food Chemistry, 135: 1290-1297. DOI:https://doi.org/10.1016/j.foodchem.2012.05.065,

Kulshreshtha G, Stratton G, Rathgeber B, Thomas N and Evan F (2014). Feed supplementation with red seaweeds, Chondrus crispus and Sarcodiotheca gaudichaudii, affects performance, egg quality, and gut microbiota of layer hens. Poultry Science, 93: 2991-3001. DOI: https://dx.doi.org/ 10.3382/ps.2014-04200.

Lee KW, Choo WD, Kang CW and An BK (2016). Effect of lycopene on the copper-induced oxidation of low-density lipoprotein in broiler chickens. Springer Plus, 5: 389. DOI: https://doi.org/10.1186/s40064-016-2035-6

Mahata ME, Manik J, Taufik M, Rizal Y and Ardi I (2016a). Effect of different combinations of unboiled and boiled tomato waste in diet on performance, internal organ development and serum lipid profile of broiler chicken. International Journal of Poultry Science, 15(7): 283-286.

Mahata ME, Rizal Y, Ardi, Hermansyah D and Nurhuda GA (2016b). Effects of boiled tomato waste utilization in the diet on serum lipid profile and egg quality of laying-hens. International Journal of Poultry Science, $15 \quad$ (12): 493-496. DOI: https://doi.org/10.3923/ijps.2016.493.496

Marti R, Leiva-Brondo M, Lahoz I, Campillo C, Cebolla-Cornejo J and Rosello S (2018). Polyphenol and L-ascorbic acid content in tomato as influenced by high lycopene genotypes and organic farming at different environments. Food Chemistry, 239: 148156. DOI: https://doi.org/10.1016/j.foodchem.2017.06.102

Mezbani A, Kavan B P, Kiani A and Masouri B (2019). Effect of dietary lycopene supplementation on growth performance, blood parameters and antioxidant enzymes status in broiler 
chickens. Livestock Research for Rural Development, 31: article \#12. Available at: http://www.lrrd.org/lrrd31/1/bahma31012.html.

Muller L, Goupy P, Frohlich K, Dangles O, Caris, Veyrat C and Bohm V (2011). Comparative study on antioxidant activity of lycopene (Z) isomers in different assays. Journal of Agricultural and Food Chemistry, 59: 4504-4511. DOI: https://doi.org/10.1021/jf010888q.

Palozzza P, Catalona A, Simone RE, Mele MC and Cittadini (2012). Effect of lycopene and tomato products on cholesterol metabolism. Annals of nutrition and metabolism, 61: 126-134.

Panaite TD, Nour V, Vlaicu PA, Ropota M, Corbu AR and Saracila M (2019). Flaxseed and dried tomato waste used together in laying hens diet, Archives of Animal Nutrition, 73 (3): 222-238. DOI: https://doi.org/10.1080/1745039X.2019.1586500.

Perveen R, Suleria HAR, Anjum FM, Butt MS, Pasha I and Ahmad S (2015). Tomato (Solanum lycopersicum) carotenoids and lycopenes chemistry; metabolism, absorption, nutrition, and allied health claims-a comprehensive review, Critical Reviews in Food Science and Nutrition, 55(7): 919-929. DOI: https://doi.org/10.1080/10408398.2012.657809.
Phillips KM, Council-Troche M, McGinty RC, Rasor AS and Tarrago Trani MT (2016). Stability of vitamin C in fruit and vegetable homogenates stored at different temperatures. Journal of Food Composition and Analysis, 45: 147-162. DOI: https://doi.org/10.1016/j.jfca.2009.08.018.

Sahlin EGP, Savage and Lister CE (2004). Investigation of the antioxidant properties of tomatoes after processing. Journal of Food Composition and Analysis, 17 (2004): 635-647.

Salajegheh MH, Ghazi S, Mahdavi R and Mozafari O (2012). Effects of different levels of dried tomato pomace on performance, egg quality and serum metabolites of laying hens. African Journal of Biotechnology, 11(87): $15373-15379 . \quad$ DOI: https://doi.org/10.5897/AJB12.1031.

Sharma SK, and Le Maguer M (1996). Lycopene in tomatoes and tomato pulp fractions. Italian Journal of Food Science, 8 (2): 107-113.

Torki M, Zangeneh S and Habibian M (2014). Performance, egg quality traits, and serum metabolite concentration of laying hens affected by dietary suplemental chromium picolinate and vitamin $\mathrm{C}$ under a heat-stress. Biological Trace Element Research, 157: 120-129. DOI: https://doi.org/10.1007/s12011-013-9872-8. 